\title{
Nonfarm activity and market participation by farmers in Ghana
}

\author{
Paul Kwame Nkegbe ${ }^{1 *} \mathbb{C}$, Abdelkrim Araar², Benjamin Musah Abu ${ }^{1}$, Hamdiyah Alhassan³, Yazidu Ustarz ${ }^{1}$, \\ Edinam Dope Setsoafia ${ }^{3}$ and Shamsia Abdul-Wahab ${ }^{1}$
}

\author{
*Correspondence: \\ pnkegbe@uds.edu.gh \\ ${ }^{1}$ Department of Economics \\ and Entrepreneurship \\ Development, University \\ for Development Studies, P. \\ O. Box 520, Wa, Upper West \\ Region, Ghana \\ Full list of author information \\ is available at the end of the \\ article
}

\begin{abstract}
This paper examines the relationship between participation in nonfarm activity and participation in markets by farm households in Ghana. The study used data from the Ghana Living Standards Survey Round 6 and employed the endogenous switching probit model which accounts for selection bias from observed and unobserved factors. The results reveal that infrastructural variables such as roads, means of transport, markets and banks are important determinants of nonfarm work engagement and participation in crop market. We also find a positive and significant effect of nonfarm work participation on the probability of selling crops. The conclusion is that farmers' engagement in nonfarm activities boosts decisions to enter crop markets in Ghana. The results of the study imply that for agricultural development in Ghana and other countries with similar characteristics, agricultural policies should incorporate strategies that enhance opportunities in the nonfarm sector as that will translate to enhanced producer market participation.
\end{abstract}

Keywords: Nonfarm work participation, Market participation, Endogenous switching probit, Ghana

\section{Introduction}

In developing economies, the role of agriculture in leading the socioeconomic transformation at the micro- and macro-levels is well documented. However, recent developments in most parts of the developing world show that there have been parallel sectors that are increasing in strength and rivalling the agriculture sector in terms of importance. One of such sectors that has come to the fore in development economics research is the rural nonfarm sector (see, for example, Ellis 2000; Reardon 1997; Reardon et al. 1994). In fact, the growth of nonfarm work among farmers is attested in developed economies as well. For example, Alasia et al. (2009) note that in Canada, there is a rise in the number of farmers who engage in nonfarm work, forcing a significant reduction in the number of farmers.

The rural nonfarm sector has been observed to exert positive externality on development outcomes of rural populations. Income earned from nonfarm activities holds the tendency to increase average household income and ultimately ease household capital and credit constraints and enhancing farmers' ability to purchase farm inputs author(s) and the source, provide a link to the Creative Commons licence, and indicate if changes were made. The images or other third party material in this article are included in the article's Creative Commons licence, unless indicated otherwise in a credit line to the material. If material is not included in the article's Creative Commons licence and your intended use is not permitted by statutory regulation or exceeds the permitted use, you will need to obtain permission directly from the copyright holder. To view a copy of this licence, visit http:// creativecommons.org/licenses/by/4.0/. 
and to adopt improved production technology (Dedehouanou et al. 2018; Babatunde 2015; Maertens 2009). This investment in farm enterprise enhances farm productivity and increases marketed surplus which encourages farmers to participate in the market (Woldehanna 2000). Nevertheless, various studies have also reported adverse effects of nonfarm activity engagements on farm activities. It has been reported that moving away resources such as land and labour previously used on-farm reduces farm productivity, which decreases marketed surplus and thus dampens market participation by farmers (see, for example, Omiti et al. 2009; Pfeiffer et al. 2009). In addition, nonfarm income if used for consumption reduces farm investment, thereby decreasing farm productivity and thus marketed surplus (Babatunde 2015).

Given the crucial role of rural nonfarm work participation on agricultural commercialisation, and the fact that agriculture remains a key sector of the economy that employs the majority of the labour force, the Government of Ghana through the Ministry of Food and Agriculture (MoFA) has formulated and implemented policies/initiatives that seek to promote nonfarm work opportunities and agricultural commercialisation through farm investment and increased crop productivity. For example, the Medium-Term Agriculture Sector Investment Plan (METASIP II) (2014-2017), METASIP III (2018-2021) and the current government flagship initiatives, namely, Planting for Food and Jobs, Planting for Export and Rural Development, and One-District-One Factory programmes all gear towards promoting livelihood diversification, farm productivity and agricultural commercialisation. All these seek to help the government achieve the Sustainable Development Goals (SDGs) 1 and 2 which focus on alleviating poverty and ending hunger by the year 2030. Despite these policies and initiatives, farmers still have numerous challenges regarding market participation and finding alternative livelihood activities.

While the policy perspective acknowledges the importance of market engagements of farmers and their participation in nonfarm work as key for poverty reduction, a key question is whether there exists a link between nonfarm work and market participation among farmers. This information, if sought, will help inform policy makers to either simultaneously tackle nonfarm engagement and market participation of farmers or treat them as independent activities. It also has serious implications for the larger policy area of poverty alleviation and hunger eradication. However, there are limited empirical studies on the effect of nonfarm activities on farmer's participation in the market.

Specifically in Ghana, studies have explored the nonfarm-farm linkages (see, e.g. Canagarajah et al. 2001; Anríquez and Daidone 2010; Owusu et al. 2011; Osarfo et al. 2016). For example, Canagarajah et al. (2001) examined the distribution of earnings by gender and income type, and the effect of nonfarm earnings on inequality. Okoh and Hilson (2011) assessed the importance of promoting and regularising artisanal and small-scale mining as a livelihood diversification from unproductive smallholder farming. Further, Anriquez and Daidone (2010) examined whether nonfarm engagement stimulates economies of diversification of farm households and the effect of nonfarm engagement on input demands and production efficiency. Though these studies examine the nonfarm-farm linkages, none of these explores the linkage in the context of market participation-the focus of this study. The combined focus of these studies has been on input demand, production efficiency, inequality, food security and welfare. Against this background, this paper aims to provide the necessary empirical content to back policies 
in these areas. Indeed, most of these policies generally have weak empirical dimensions and providing evidence that informs us on the specific relationship between promoting diversification through nonfarm engagement and market participation is worthwhile. Against this background, the current study examines the effect of nonfarm activities on market participation of farmers in Ghana.

In other places, however, empirical studies have been conducted on the effect of nonfarm engagement on market participation just as this present study aims at achieving. For example, Kan et al. (2006), Tudor and Balint (2006), and Woldehanna et al. (2016) have conducted studies on the link between nonfarm activity and market participation. However, these studies are largely descriptive or focus only on farmers who engaged in nonfarm activities. Other studies have focused on the linkage between nonfarm activities and income inequality, poverty reduction and food security (see, e.g. Alemu and Adesina 2017; Seng 2016; Hoang et al. 2014). Thus, this study contributes to the literature by its specific focus on market participation and it does so by using a modelling approach - the endogenous switching probit model-which allows us to examine the drivers of market participation of nonfarm participants and non-participants on one hand, and the estimates of the effect of nonfarm participation on farmer's sale of crops in the market on the other.

The rest of the paper is as follows. While the next section reviews relevant literature, theoretical and conceptual issues are presented immediately after it. The next section describes the method and data used and the following section discusses the main findings of the study. The final section then concludes with policy implications.

\section{Literature review}

Several factors have been identified in the literature that explain why farm households may diversify their labour into nonfarm activities. From the observation of Barrett et al. (2001) and Reardon et al. (2007), nonfarm participation emanates from 'demand-pull' and 'distress-push' factors. Kilic et al. (2009) explain that when farmers allocate labour to nonfarm work because its returns to labour outweigh that from farm work, then they are said to be pulled into nonfarm work. On the other hand, Woldehanna and Oskam (2001), and Holden et al. (2004) explain that when farmers allocate labour to nonfarm work because they wish to steer away from shocks and risks from farming, they are said to be pushed to nonfarm work. There are studies examining the determinants of engaging in nonfarm work. In this regard, studies mostly conclude that characteristics of households such as education, ethnicity, skills, and gender; assets, financial and social capital; and physical infrastructure and information affect participation in nonfarm work in important ways. For example, Ackah (2013) and Olugbire et al. (2012) identified land size, education, and gender as determinants of nonfarm work. In a similar vein, Benedikter et al. (2013) observed that education, level of savings, prior work experience, and social capital were the main drivers of nonfarm work, while Reardon (1997) identified location as significant in households' decisions to engage in nonfarm activities.

Conceptually, it is hypothesised that engagement in nonfarm work may encourage smallholder market participation if used as a liquidity source for investment in the farm; which may enhance yield and marketable surplus (Woldehanna 2000). On the other hand, if nonfarm income is used for consumption and other non-agricultural 
investments instead of farm investment, then nonfarm work becomes a competitor. This is because nonfarm work may compete with on-farm work for labour and other resources, a situation which, in turn, lowers production and marketable surplus. On the basis of these hypotheses, a number of studies have investigated the linkage between nonfarm engagement of farm households and their market participation decisions. Using the sequential simultaneous equations model, Kan et al. (2006) reported that nonfarm income negatively affects market participation. Tudor and Balint (2006) employing descriptive and correlation analyses also identified a positive correlation between nonfarm employment and agricultural commercialisation. Woldehanna et al. (2016) adopted a double-hurdle model to examine the link between off-farm income and output market participation decisions and reported that off-farm income has no significant effect on output market participation in Ethiopia. Abdullah et al. (2019) found that income from off-farm activities increased the probability of household market participation. Chang et al. (2017) reported that husbands' nonfarm labour positively affected marketing, while the reverse was observed for farm wives.

Further studies assessed the channels through which nonfarm engagement affect market participation, with different results. For example, Babatunde (2015) revealed that while nonfarm income reduces family labour use, it contributes positively to expenses on purchased inputs. Smale et al. (2016) observed a negative effect of nonfarm income sources on fertiliser use in maize production in Kenya. In Senegal, Maertens (2009) found that nonfarm income increases household farm investment. Similarly, Dedehouanou et al. (2018) reported that nonfarm participation increases agricultural expenditure on purchased inputs and hired labour in rural Niger. In Ghana, Anriquez and Daidone (2010) observed that expansion of the nonfarm sector increases demand for agricultural inputs including farmlands. Anang (2017) found that nonfarm participation positively affects productivity in Ghana, while Yang et al. (2014) found that technical efficiency increases for grain producers who engaged in nonfarm activities in China. In contrast, Pfeiffer et al. (2009) indicated that nonfarm income is negatively associated with the value of agricultural output and family labour.

The review reveals that comparatively, studies on nonfarm and farm linkages from the perspective of market participation (e.g. Woldehanna et al. 2016; Kan et al. 2006; Tudor and Balint 2006) are either merely descriptive or concentrate on only farmers who participated in nonfarm activities. The estimation techniques employed by these previous studies failed to estimate the causal effect of nonfarm activity on market participation, a gap this current study seeks to fill.

\section{Theoretical and conceptual issues}

In the empirical literature, the main theoretical explanation for a connection between the nonfarm and the farm sectors is the explanation provided by Singh et al. (1986). They explain that given household endowment of labour and other available resources, the household makes allocation decisions based on which sector provides the greatest utility in the form of returns from the allocation. Thus, in terms of labour allocation between farm and nonfarm sectors, a typical household would allocate more labour to the sector that provides the highest returns. An important empirical assessment of the connection 
between the nonfarm sector and the farm sector is the examination of the effect of nonfarm engagement by households and the sale of their produce.

In this study, nonfarm activities are defined as all activities that farm households engage in away from their primary farm activities to earn extra income. Concentrating only on agricultural households, all their economic activities that are performed outside agriculture are classified as nonfarm activities. These economic activities include handicrafts, household and non-household small-scale manufacturing, construction, mining, quarrying, repair, transport, petty trading, among others. The concept of market participation is viewed in different ways by different authors (Otekunrin et al. 2019). However, it is generally observed to imply farm households engaging with markets either as sellers or buyers (Barrett 2008). They participate as sellers to dispose their surplus produce and participate as buyers to procure food and farm inputs. Market participation is also observed to embody two related decisions: farm households deciding to sell their surplus produce in a first-place decision and then deciding the quantity to sell in a secondplace decision. In this study, we focus on the first-place decision to sell crop produce as the definition of market participation. This definition has been used in earlier studies (see, e.g. Alhassan et al. 2020; Abu et al. 2016; Muamba 2011).

The literature provides two theoretical transmission mechanisms of the association between nonfarm engagement and market participation of farmers (see Reardon et al. 1994; Woldehanna 2000; Woldehanna and Oskam 2001; Babatunde 2015). The first theoretical channel is referred to as the liquidity-relaxing channel. This channel argues that when labour is allocated to nonfarm activities, households derive income which generally increases their liquidity. This gives the opportunity to escape cash constraints and provides the platform for households to invest more in farm activities. For example, households can invest to adopt appropriate technology to boost productivity. In this case, this theoretical channel would boost market participation of farmers. The second theoretical channel is referred to as the lost-labour channel. The argument this channel poses is that if labour allocation in nonfarm activities that generates income is invested in nonfarm enterprises and consumption, it promotes diversion from further investments in farm activities. In this case, this channel would dampen market participation due to the shift from farm investments and competition for labour for farm work (Babatunde 2015).

The conceptual underpinning of this underlying link between nonfarm engagement and market participation is presented in Fig. 1. The figure indicates that total household labour is allocated between farm and nonfarm sectors. The use of labour in the farm sector produces output which is distributed between consumption and marketed surplus. Based on the marketed surplus, a household can make the decision to sell. On the other hand, labour allocated to the nonfarm sector produces income which is also distributed between investments in the farm sector and consumption. As stipulated by the liquidity-relaxing theory, investment in the farm sector happens because the nonfarm income curtails capital constraints. This ultimately boosts market participation. However, if the nonfarm income is invested in consumption activities, this dampens market participation due to the gradual shifts of more labour to nonfarm activities.

Based on the theoretical and conceptual considerations, it is expected that nonfarm engagement would either positively or negatively influence market participation of 


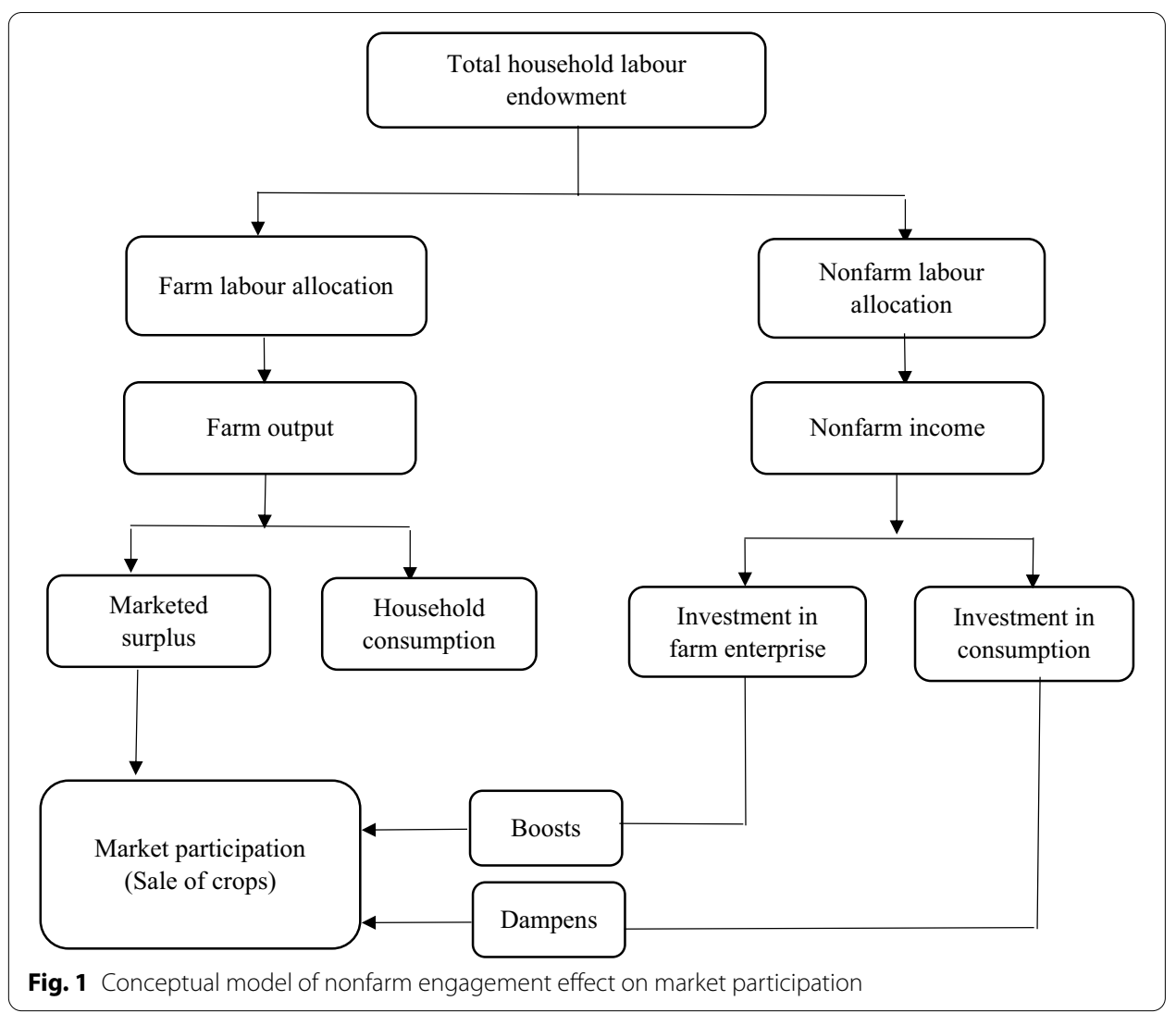

farmers. The positive influence is expected due to the liquidity-relaxing theoretical channel and the negative influence is expected due to the lost-labour theoretical channel.

In the context of Ghana, we argue in favour of the liquidity-relaxing hypothesis pathway and thus expect a positive effect of nonfarm engagement on market participation. We justify our expectation following empirical evidence from Okoh and Hilson (2011), Hilson (2010), and Hilson and Garforth (2013). First, Okoh and Hilson (2011) provide evidence that shows that smallholder farmers' diversification into artisanal and small-scale mining yields finances that are ploughed back into agriculture by way of purchasing important agricultural inputs such as fertilisers and herbicides. Further, Hilson (2010), and Hilson and Garforth (2013) observed that smallholder farmers who initially abandoned their farm activities in favour of artisanal and small-scale mining did so for a while and later returned to 'reorient' their farm activities using the income from the mining. A second justification for our expectation is based on the general credit constraints faced by farmers in the literature (e.g. Sekyi et al. 2017; Hussain and Thapa 2016; Akudugu et al. 2012). In the specific case of Ghana, Sekyi et al. (2017) and Akudugu et al. (2012) have emphasised credit constraints faced by Ghanaian farmers. In the light of this, farmers may decide to diversify into nonfarm activities as a derived demand-that is, to raise nonfarm income to invest in their farm activities. 


\section{Methods and data}

\section{Econometric specification}

A mathematical representation that serves to translate the link between market participation and nonfarm engagement (presented in the conceptual model in Fig. 1) can be generally specified as:

$$
\mathrm{MP}_{j}=f\left(X_{j}, \mathrm{NFE}_{j}\right)
$$

where MP is market participation (which is a dummy equal to 1 if a household sold a particular crop and 0 otherwise) of the $j$ household, NFE is the nonfarm indicator (which is a dummy equal to 1 if a household participates in nonfarm activities and 0 otherwise), $X$ is all other explanatory variables that are hypothesised to influence market participation. A specific econometric model flowing from Eq. (1) is stated as:

$$
\mathrm{MP}_{j}=X_{j} \alpha+\delta \mathrm{NFE}_{j}+\varepsilon_{j}
$$

where $\delta$ is the estimated effect of nonfarm engagement on market participation. Since MP is a binary outcome, $\delta$ can be estimated using a conventional univariate probit model under two assumptions-normal distribution of $\varepsilon$ and NFE not endogenous. While the first assumption can be easily explained away, the second cannot. In the market participation literature, engagement in NFE and sale of crops (MP) are potentially endogenous due to a potential reverse causality. Farm households may engage in nonfarm activities to raise income for investments in farm activities such as purchase of inputs that could culminate in producing beyond consumption needs to participate in markets, which is what this study wishes to explore. However, participating in the market has the potential to increase farm households' income which can be invested in nonfarm enterprises. Further, endogeneity may originate from an omitted variable bias, where the possibility of the existence of some unobservable factors such as innate farmers' attitude towards entrepreneurship jointly determine NFE and MP. Due to the potential simultaneous nature, modelling these two variables with univariate probit models would lead to biased and inconsistent estimates.

One notable econometric procedure that embraces, first, the potential endogenous nature of MP and NFE and second, the discrete nature of the outcome variable (i.e. MP) is the endogenous switching probit model developed by Lokshin and Sajaia (2011). This model proposes a switch in the outcome (MP) based on treatment status (NFE) and implements full information maximum likelihood procedure to simultaneously estimate the binary selection and the binary outcome parts of the model to yield consistent standard errors of the estimates.

Assume that a household decision-making process regarding participation in nonfarm activities sorts households into two regimes of their market participation status (those that participate and those that do not participate) in the form:

$$
\begin{cases}\mathrm{NFE}_{i}=1 & \text { if } Z_{j} \beta+H_{j} \eta+\varepsilon_{j}>0 \\ \mathrm{NFE}_{i}=0 & \text { if } Z_{j} \beta+H_{j} \eta+\varepsilon_{j} \leq 0\end{cases}
$$


Regime 1: $\mathrm{MP}_{1 j}^{*}=X_{1 j} \alpha_{1}+\varepsilon_{1 j}$ and $\mathrm{MP}_{1 j}=I\left[\mathrm{MP}_{1 j}^{*}>0\right]$

Regime 0: $\mathrm{MP}_{0 j}^{*}=X_{0 j} \alpha_{0}+\varepsilon_{0 j}$ and $\mathrm{MP}_{0 j}=I\left[\mathrm{MP}_{0 j}^{*}>0\right]$

The observed $\mathrm{MP}_{j}$ is defined as:

$$
\begin{cases}\mathrm{MP}_{j}=\mathrm{MP}_{1 j} & \text { if } \mathrm{NFE}_{i}=1 \\ \mathrm{MP}_{j}=\mathrm{MP}_{0 j} & \text { if } \mathrm{NFE}_{i}=0\end{cases}
$$

where $\mathrm{MP}_{1 j}^{*}$ and $\mathrm{MP}_{0 j}^{*}$ are the latent variables (probability of selling crops) that influence the observed binary outcomes $\mathrm{MP}_{1}$ and $\mathrm{MP}_{0}$ (whether the household sells crops or otherwise); Regime 1 represents farmers who engage in NFE (NFE participants), Regime 0 represents farmers who do not engage in NFE (NFE non-participants); $X_{1}$ and $X_{0}$ are vectors of variables determining the respective outcome equations; $Z$ is a vector of variables that are hypothesised to influence NFE; $H$ is a vector of exclusion restriction variables that are by nature correlated with NFE but uncorrelated with MP. We use two variables to play this role: ease of finding job in a community and people leaving the community temporarily. We argue that when it is easy to find jobs in a community, the likelihood of allocating time for nonfarm work increases. Also, temporarily leaving a community is more associated with finding alternative work, especially in the lean farming season. $\alpha_{1}, \alpha_{0}$ and $\beta$ are vectors of parameters; and $\varepsilon_{j}, \varepsilon_{1 j}$ and $\varepsilon_{0 j}$. are the error terms. We assume that the error terms are jointly normally distributed, with a mean-zero vector and correlation matrix:

$$
\Omega=\left[\begin{array}{ccc}
1 & \rho_{0} & \rho_{1} \\
& 1 & \rho_{10} \\
& & 1
\end{array}\right]
$$

where $\rho_{0}$ and $\rho_{1}$ are, respectively, the correlions between $\varepsilon_{0}$ and $\varepsilon$, and $\varepsilon_{1}$ and $\varepsilon$. $\rho_{10}$ is the correlation between $\varepsilon_{0}$ and $\varepsilon_{1}$. However, since $\mathrm{MP}_{1 j}$ and $\mathrm{MP}_{0 j}$ are mutually exclusive in observation, $\rho_{10}$ is unidentified and inestimable, and thus constrained to 1 .

The log-likelihood function for the simultaneous system of Eqs. (3) to (5) is expressed as:

$$
\begin{aligned}
\ln (\varsigma)= & \sum_{\mathrm{NFE}_{i} \neq 0, \mathrm{MP}_{i} \neq 0} w_{j} \ln \left\{\Phi_{2}\left(X_{1 j} \alpha_{1}, Z_{j} \beta, \rho_{1}\right)\right\} \\
& +\sum_{\mathrm{NFE}_{i} \neq 0, M P_{i}=0} w_{j} \ln \left\{\Phi_{2}\left(-X_{1 j} \alpha_{1}, Z_{j} \beta,-\rho_{1}\right)\right\} \\
& +\sum_{\mathrm{NFE}_{i}=0, \mathrm{MP}_{i} \neq 0} w_{j} \ln \left\{\Phi_{2}\left(X_{0 j} \alpha_{0},-Z_{j} \beta, \rho_{0}\right)\right\} \\
& +\sum_{\mathrm{NFE}_{i}=0, \mathrm{MP}_{i}=0} w_{j} \ln \left\{\Phi_{2}\left(-X_{0 j} \alpha_{0},-Z_{j} \beta, \rho_{0}\right)\right\}
\end{aligned}
$$

where $\Phi_{2}$ is the cumulative function of a bivariate normal distribution and $w_{i}$ is an optional weight for observation $j$. An added advantage of the model is its capacity to deal with selectivity bias through the joint modelling of the error terms of NFE (i.e. $\varepsilon_{j}$ ) and 
MP (i.e. $\varepsilon_{1 j}$ and $\varepsilon_{0 j}$ ). This is welcoming, especially in situations where observations are dropped from the original sample that may introduce selection bias in the final sample.

After estimating the various parameters of the model, traditional treatment effects (i.e. ATT, ATU and ATE) of NFE on MP can be derived by first deriving the respective total effects as:

$$
\begin{aligned}
\mathrm{TT}(x) & =\operatorname{Pr}\left(\mathrm{MP}_{1}=1 \mid \mathrm{NFE}=1, X=x\right)-\operatorname{Pr}\left(\mathrm{MP}_{0}=1 \mid \mathrm{NFE}=1, X=x\right) \\
& =\frac{\Phi_{2}\left(X_{1} \alpha_{1}, Z \beta, \rho_{1}\right)-\Phi_{2}\left(X_{0} \alpha_{0}, Z \beta, \rho_{0}\right)}{F(Z \beta)} \\
\mathrm{TU}(x) & =\operatorname{Pr}\left(\mathrm{MP}_{1}=1 \mid \mathrm{NFE}=0, X=x\right)-\operatorname{Pr}\left(\mathrm{MP}_{0}=1 \mid \mathrm{NFE}=0, X=x\right) \\
& =\frac{\Phi_{2}\left(X_{1} \alpha_{1},-Z \beta,-\rho_{1}\right)-\Phi_{2}\left(X_{0} \alpha_{0},-Z \beta,-\rho_{0}\right)}{F(-Z \beta)} \\
\mathrm{TE}(x) & =\operatorname{Pr}(\mathrm{NFE}=1, X=x)-\operatorname{Pr}(\mathrm{NFE}=0, X=x)=F\left(X_{1} \alpha_{1}\right)-F\left(X_{0} \alpha_{0}\right)
\end{aligned}
$$

where $\mathrm{TT}(x)$ is the effect of the treatment (NFE) on the treated households with a vector of observed characteristics $x ; \mathrm{TU}(x)$ is the effect of the treatment on the untreated households with a vector of observed characteristics $x ; \mathrm{TE}(x)$ is the treatment effect of a household randomly drawn from the population with a vector of observed characteristics $x$; and $F$ is a cumulative function of the univariate normal distribution.

From the total effects in Eqs. (8) to (10), the average treatment effects (ATT, ATU and ATE) can be estimated by taking the average of each total effect over the samples in each effect group. Thus, the respective effects are:

$$
\begin{aligned}
& \mathrm{ATT}=\frac{1}{N_{T}} \sum_{j=1}^{N_{T}} \mathrm{TT}(x) \\
& \mathrm{ATU}=\frac{1}{N_{T}} \sum_{j=1}^{N_{T}} \mathrm{TU}(x) \\
& \mathrm{ATE}=\frac{1}{N_{T}} \sum_{j=1}^{N_{T}} \operatorname{TE}(x)
\end{aligned}
$$

where $N_{T}$ is the sample size in each effect group.

The Average Treatment Effect on the Treated (ATT) measures the difference in the effect of participating in nonfarm activity on market participation relative to not participating in nonfarm activity. Thus, it measures the true effect of nonfarm engagement. The Average Treatment Effect (ATE) on the other hand captures the difference in effect on market participation of those who participate in nonfarm activity and those who do not participate in nonfarm activity. The choice of prioritising ATE and ATT basically depends on policy interest. ATE is prioritised over ATT when policy interest is to promote nonfarm participation among farmers in Ghana; while ATT is prioritised over ATE when the interest is only to promote nonfarm participation among the sample of farmers. In randomised assessments, the ATT would have been 
Table 1 Description and measurement of variables

\begin{tabular}{|c|c|}
\hline Variable description & Measurement \\
\hline \multicolumn{2}{|l|}{ Dependent variables } \\
\hline Engaged in nonfarm activity & $1=$ if yes; $0=$ otherwise \\
\hline Sold crop & $1=$ if yes; $0=$ otherwise \\
\hline \multicolumn{2}{|l|}{ Explanatory variables } \\
\hline Age of household head & Years \\
\hline Average age of household & Years \\
\hline Sex of household head & $1=$ if male; $0=$ otherwise \\
\hline Years of education of head & Years spent in school \\
\hline Area of residence & $1=$ if rural; $0=$ otherwise \\
\hline Region of residence & Dummy for each region \\
\hline Farm size & Hectare \\
\hline Price/kg & Ghana cedi/kilogram \\
\hline Extension office in community & $1=$ if yes; $0=$ otherwise \\
\hline Agricultural wage & Ghana cedi \\
\hline Ecological zone & Dummy for each zone \\
\hline Adult equivalent scale & Scale \\
\hline Market in community & $1=$ if yes; $0=$ otherwise \\
\hline Navigable road to community & $1=$ if yes; $0=$ otherwise \\
\hline Public transport availability & $1=$ if yes; $0=$ otherwise \\
\hline Ownership of radio & $1=$ if yes; $0=$ otherwise \\
\hline Bank in community & $1=$ if yes; $0=$ otherwise \\
\hline Ease of finding jobs in community & $1=$ if easy $; 0=$ otherwise \\
\hline People temporarily leave community & $1=$ if yes; $0=$ otherwise \\
\hline
\end{tabular}

enough since it would have been similar to the ATE. However, since we are using cross-sectional data and a quasi-experimental approach to estimating the treatment effects, both the ATT and ATE would be estimated and discussed. However, the ATE would be prioritised since it concerns farmers in general.

\section{Data}

The study used the Ghana Living Standards Survey round 6 (GLSS 6) household-level dataset. This dataset was collected by the Ghana Statistical Service (GSS) between October 2012 and October 2013. The purpose of the survey is to generate information on living conditions in the country. It used a questionnaire adapted from the World Bank's Living Standards Measurement Survey and covers a stratified and nationally representative, random sample of 16,772 households in 1,200 enumeration areas. The GLSS 6 focuses on the household as the key socioeconomic unit. Detailed information was collected on the demographic characteristics of households, education, health, employment, migration and tourism, housing conditions, household agriculture, household expenditure, income and their components and access to financial services, credit and assets. Other modules administered in the survey were the nonfarm household enterprises, household access to financial services and governance, peace and security. The specific variables, their description and measurement are presented in Table 1. 
Table 2 Descriptive statistics of variables

\begin{tabular}{|c|c|c|c|c|c|c|c|}
\hline \multirow[t]{2}{*}{ Variable } & \multicolumn{2}{|c|}{$\begin{array}{l}\text { NFE participants } \\
(n=1,616)\end{array}$} & \multicolumn{2}{|c|}{$\begin{array}{l}\text { NFE non- } \\
\text { participants } \\
(\mathrm{n}=3,299)\end{array}$} & \multicolumn{3}{|c|}{ Overall $(n=4,915)$} \\
\hline & Mean $^{a}$ & S.D & Mean & S.D & Mean & S.D & Diff \\
\hline Nonfarm engagement & - & - & - & - & 0.329 & 0.470 & \\
\hline Sold crop & 0.603 & 0.489 & 0.615 & 0.487 & 0.611 & 0.488 & -0.002 \\
\hline Age of household head & 47.98 & 14.05 & 48.12 & 16.31 & 48.08 & 15.61 & -0.371 \\
\hline Average age of household & 34.16 & 8.783 & 33.45 & 12.14 & 33.68 & 11.17 & $0.451^{*}$ \\
\hline Sex of household head & 0.827 & 0.378 & 0.808 & 0.394 & 0.814 & 0.389 & $0.026^{* * *}$ \\
\hline Years of education of head & 5.607 & 4.454 & 4.005 & 4.217 & 4.526 & 4.360 & $1.100^{* * *}$ \\
\hline Area of residence & 0.968 & 0.175 & 0.976 & 0.153 & 0.974 & 0.160 & $-0.011^{* *}$ \\
\hline Farm size in hectares & 1.609 & 2.742 & 2.046 & 14.40 & 1.904 & 11.94 & -0.159 \\
\hline Price/kg & 4.322 & 3.777 & 4.162 & 3.754 & 4.214 & 3.762 & $0.855^{* * *}$ \\
\hline Extension office in community & 0.183 & 0.387 & 0.155 & 0.362 & 0.164 & 0.370 & 0.002 \\
\hline Agricultural wage & 8.860 & 4.475 & 8.639 & 5.014 & 8.711 & 4.846 & 0.086 \\
\hline Adult equivalent scale & 4.435 & 2.329 & 3.651 & 2.214 & 3.906 & 2.281 & $0.857^{* * *}$ \\
\hline Market in community & 0.280 & 0.449 & 0.296 & 0.456 & 0.290 & 0.454 & -0.002 \\
\hline Navigable road to community & 0.469 & 0.499 & 0.790 & 0.408 & 0.685 & 0.464 & $-0.351^{* * *}$ \\
\hline Public transport availability & 0.606 & 0.489 & 0.512 & 0.500 & 0.543 & 0.498 & $0.088^{* * *}$ \\
\hline Ownership of radio & 0.621 & 0.485 & 0.633 & 0.482 & 0.629 & 0.483 & 0.007 \\
\hline Bank in community & 0.079 & 0.269 & 0.046 & 0.209 & 0.056 & 0.231 & $0.024^{* * *}$ \\
\hline Ease of finding jobs & 0.387 & 0.487 & 0.343 & 0.475 & 0.357 & 0.479 & $0.044^{* * *}$ \\
\hline People temporary leave & 0.782 & 0.413 & 0.758 & 0.428 & 0.766 & 0.423 & $0.024^{* *}$ \\
\hline
\end{tabular}

${ }^{a}$ Means/averages for dummy variables are proportions/percentages for the ' 1 ' groups for the various variables; sampling weight is used; Diff. represents the mean difference; ${ }^{*} p<0.1 ;{ }^{* *} p<0.05 ;{ }^{* * *} p<0.01$

Disaggregating the entire sample $(16,772)$ based on crops cultivated showed that only five crops had large number of farmers cultivating them. These are maize, groundnut, rice, beans and sorghum. Thus, cereals (maize, rice, and sorghum) and legumes (groundnut and beans) were heavily cultivated in the 2012/2013 production season and depict the situation of crop production in Ghana.

The various samples of farmers who cultivated these crops are 4437 for maize; 1730 for groundnut; 1157 for rice; 1371 for beans; and 997 for sorghum. We combined these crops into an aggregate sample and obtained a final sample of $4915 .{ }^{1}$ The analyses are based primarily on the aggregated sample. However, crop level analyses are done to provide robustness checks.

\section{Results and discussion}

\section{Descriptive characteristics of the sample}

The descriptive statistics of variables used in this study are presented in Table 2. Participation in nonfarm activities can be described as low since $32.9 \%$ of farmers is recorded as nonfarm participants. Given the characteristic of agriculture being predominant in rural areas, the low nonfarm participation rate may be attributable to inadequate opportunities to farmers to engage in nonfarm activities rather than the theoretical argument

\footnotetext{
${ }^{1}$ The final sample is not 9692 (that is, the sum of all samples). This is because, maize is the basic crop and so, most households who cultivated the other four crops (groundnut, rice, beans, and sorghum) also cultivated maize.
} 
of agriculture yielding higher returns in relative terms. For market participation, an average of $61.1 \%$ of farmers sold at least one crop. Its distribution over nonfarm participation status indicates that, respectively, $60.3 \%$ and $61.5 \%$ of the participants and the non-participants sold their produce.

The statistics also indicate that farmers have low education levels as the overall average years spent in school is 5 . This corresponds to just about half of the duration for basic level of education. This depicts the picture of Ghanaian agriculture where the sector is dominated by people without formal education. The inadequate modernisation in the sector makes it unattractive to educated elites. This assertion is supported by the statistics pertaining to locality where about $97 \%$ of the farmers reside in rural areas. The same trend is recorded for scale of farming where nonfarm non-participants cultivate 2.046 ha relative to 1.609 ha cultivated by participants in nonfarm activities. The price/kg is low as the average price $/ \mathrm{kg}$ is GHS4.214. ${ }^{2}$ Other facilitating ingredients to farming are also low. For example, only $16.4 \%$ of farmers reside in communities with an extension office, only $29.0 \%$ come from communities with market infrastructure and only $5.6 \%$ come from communities with banks. The low presence of these ancillary services and infrastructure has repercussions on agricultural development.

\section{Effect of nonfarm engagement on market participation}

Table 3 presents the underlying estimates of the endogenous switching probit regression model, which involve the determinants of nonfarm engagement and market participation. Column 1 corresponds to the estimates of Eq. (3) and columns 2 and 3, respectively, correspond to the regime estimates of Eq. (4) and Eq. (5). As an additional robustness check, estimates of the models for individual crops are presented in Table 5 (in the Appendix).

The results show that average age of household, years of education, price $/ \mathrm{kg}$, access to navigable roads, public transport availability, adult equivalent scale (a proxy for household size) and availability of a bank in the community increased the probability of engaging in nonfarm activities while age of head, area of residence, agricultural wages and farm size reduced that probability.

Generally, these estimates meet a priori expectations. For example, the positive estimate of adult equivalent scale, which is a proxy for household size, implies that larger households are more likely to engage in nonfarm activities because they require more financial resources to meet basic household expenditures. In addition, an increase in the level of education of the head of the household increases the probability of participation in nonfarm activities because some level of education is a pre-requisite for securing a number of jobs outside farming. Moreover, the positive estimates of navigable roads and public transport availability suggest that households who benefit from such infrastructure have a relative ease to travel to urban centres to search for nonfarm opportunities. Thus, lower transaction costs facilitate the engagement in nonfarm activities.

Further, because an increase in agricultural wages decreases the probability that a household will engage in nonfarm activities, an increase in agricultural wage apparently

${ }^{2}$ According to the Bank of Ghana, the average annual interbank exchange rate for 2013 (at the time of data collection) stood at USD 1: GHS 2. 
Table 3 Determinants of nonfarm activity and sale of crops

\begin{tabular}{|c|c|c|c|}
\hline \multirow[t]{2}{*}{ Variable } & \multirow[t]{2}{*}{ NFE } & \multicolumn{2}{|l|}{ Sale of crop } \\
\hline & & Participants & Non-participants \\
\hline \multicolumn{4}{|l|}{ Basic household characteristics } \\
\hline Age of household head & $-0.003^{* *}$ & -0.002 & $-0.006^{* * *}$ \\
\hline Average age of household & $0.005^{* * *}$ & 0.001 & -0.002 \\
\hline Sex of household head & -0.017 & $-0.219^{*}$ & $0.237^{* * *}$ \\
\hline Years of education of head & $0.039^{* * *}$ & 0.004 & $-0.027^{* * *}$ \\
\hline Area of residence & $-0.260^{* *}$ & 0.321 & 0.200 \\
\hline \multicolumn{4}{|l|}{ Region (base: Upper West) } \\
\hline Western & $-0.211^{*}$ & $0.503^{* *}$ & $0.770^{* * *}$ \\
\hline Central & 0.366 & $5.031^{* * *}$ & 0.362 \\
\hline Greater Accra & $0.196^{*}$ & $0.563^{* * *}$ & $0.386^{* * *}$ \\
\hline Volta & $0.444^{* * *}$ & $0.608^{* * *}$ & $0.259^{* *}$ \\
\hline Eastern & 0.121 & 0.316 & $(0.123)$ \\
\hline Ashanti & 0.098 & $0.446^{*}$ & $0.733^{* * *}$ \\
\hline Brong Ahafo & 0.053 & $0.599^{* *}$ & $(0.137)$ \\
\hline Northern & -0.219 & $-0.678^{* *}$ & $0.420^{* * *}$ \\
\hline Upper East & $0.629^{* * *}$ & $0.588^{* *}$ & $(0.140)$ \\
\hline \multicolumn{4}{|l|}{ Production determinants } \\
\hline Farm size in hectares & $-0.003^{*}$ & $0.122^{* * *}$ & $0.092^{* * *}$ \\
\hline Price/kg & $0.005^{* *}$ & $0.048^{* * *}$ & $0.017^{* * *}$ \\
\hline Extension office in community & & $0.084^{* *}$ & 0.066 \\
\hline Agricultural wage & $-0.009^{* *}$ & -0.006 & $0.011^{* *}$ \\
\hline \multicolumn{4}{|l|}{ Ecological zone (base: Coastal) } \\
\hline Forest & -0.140 & 0.233 & 0.120 \\
\hline Savannah & $-0.441^{* * *}$ & $0.534^{* *}$ & $0.523^{* * *}$ \\
\hline Adult equivalent scale & $0.113^{* * *}$ & $-0.037^{*}$ & $-0.069^{* * *}$ \\
\hline \multicolumn{4}{|l|}{ Other sales determinants } \\
\hline Market in community & -0.039 & $0.118^{* *}$ & $0.146^{* * *}$ \\
\hline Navigable road to community & $1.171^{* * *}$ & $2.798^{* * *}$ & $0.826^{* * *}$ \\
\hline Public transport availability & $0.464^{* * *}$ & $0.070^{* *}$ & $0.070^{*}$ \\
\hline Ownership of radio & 0.031 & $0.150^{*}$ & $0.159^{* * *}$ \\
\hline Bank in community & $0.367^{* * *}$ & 0.112 & $0.031^{*}$ \\
\hline Ease of finding jobs in community & $0.124^{* * *}$ & & \\
\hline People temporarily leave community & $0.140^{* * *}$ & & \\
\hline Constant & $-0.344^{* *}$ & $-1.990^{* * *}$ & $-1.321^{* * *}$ \\
\hline Observations & & 4915 & \\
\hline Wald chi2 & & $991.73^{* * *}$ & \\
\hline Log Pseudo likelihood & & -5013.08 & \\
\hline Rho & & $-0.999^{* * *}$ & $-0.811^{* * *}$ \\
\hline Wald test & & $26.23^{* * *}$ & \\
\hline
\end{tabular}

Source: GLSS6 Data; ${ }^{*} p<0.1 ;{ }^{* *} p<0.05 ;{ }^{* * *} p<0.01$

motivates farmers to stay on the farm. A key motivation for nonfarm engagement is a desire to supplement meagre agriculture earnings, particularly in developing countries. The results also suggest that when farmers increase the scale of production (i.e. farm size), the probability of engaging in nonfarm work reduces. This is expected because an increase in the scale of farm operation will require additional labour. Households can 
Table 4 Estimates of the effect of nonfarm engagement on market participation

\begin{tabular}{lllllll}
\hline Effect $^{\mathbf{a}}$ & All crops & \multicolumn{2}{l}{ Individual crops $^{\mathbf{b}}$} \\
\cline { 3 - 7 } & & Maize & Groundnut & Rice & Beans & Sorghum \\
\hline ATT & 0.505 & 0.377 & 0.107 & 0.231 & 0.280 & 0.088 \\
& $(0.325)$ & $(0.441)$ & $(0.887)$ & $(0.201)$ & $(0.169)$ & $(0.158)$ \\
ATU & 0.209 & 0.303 & 0.307 & 0.648 & 0.572 & 0.108 \\
& $(0.239)$ & $(0.369)$ & $(0.407)$ & $(0.158)$ & $(0.139)$ & $(0.175)$ \\
ATE & 0.307 & 0.330 & 0.229 & 0.460 & 0.465 & 0.099 \\
& $(0.225)$ & $(0.346)$ & $(0.581)$ & $(0.150)$ & $(0.105)$ & $(0.167)$ \\
\hline
\end{tabular}

Figures in parentheses are standard deviations

${ }^{a}$ Because we are using cross-sectional data and a quasi-experimental approach to estimating treatment effects, we display the estimates of ATT and ATE together

${ }^{\mathrm{b}}$ In the individual crop estimations, convergence problems were encountered, and some variables had to be dropped before achieving convergence. Therefore, the results cannot be compared to the results from the 'all crop' estimations. They are only to show how robust the effect of NFE is

meet this increased demand by reallocating labour away from nonfarm work. In terms of the area of residence variable, the negative estimate implies that rural farmers have lower probability of engaging in nonfarm work relative to urban farmers. This also meets expectation because there are more nonfarm opportunities in urban areas than in rural areas.

The determinants of the market participation of participants and non-participants in nonfarm activities indicate that except gender (which has differential effect) and adult equivalent scale (which has negative effect), farm size, price/kg, market in the community, navigable road in the community, public transport availability and ownership of radio simultaneously positively determine the two regimes. These estimates are also generally consistent with expectations. For example, market in the community, access to public transport and having navigable roads reduce transaction costs of transporting produce to market and thus, these facilitate the sale of crops. Therefore, these infrastructure variables show that reducing transaction costs in agricultural marketing increases the probability of selling. Also, an increase in the scale of production (a proxy for output) increases the likelihood of selling because it provides an opportunity to generate marketable surplus to enter markets. Moreover, higher prices increase the probability that a household will consider entering the market because a high-price signal provides an incentive to generate marketable surplus. The positive effect of ownership of a radio implies that a radio provides an avenue for marketing information that facilitates selling of crops. This is consistent with the findings of Alhassan et al. (2020) and Abu et al. (2016). On the other hand, the negative estimate of the adult equivalent scale implies that a higher scale places more demand on food consumption and thus, reduces marketable surplus that can be generated. This corroborates the findings of Alhassan et al. (2020) and Abu et al. (2016).

From estimates of the endogenous switching probit determinants of nonfarm engagement and market participation (i.e. Eqs. 3, 4 and 5), the treatment effects of nonfarm engagements on market participation were predicted, and the results are presented in Table 4.

The ATT row corresponds to the estimates of Eq. (11), the ATU row corresponds to the estimates of Eq. (12) and the ATE row corresponds to the estimates of Eq. (13). First, 
we estimate the effect of nonfarm engagement on the joint participation in the market for all the five crops. The conditional average treatment effect shows that participation in nonfarm activities increases the probability of participating in the market by $50.5 \%$ controlling for all observable characteristics. This finding deviates from that of Woldehanna et al. (2016) who report that nonfarm engagement does not affect household market participation. Subsequent estimates indicate that the crop-specific ATTs are positive, further affirming the crop aggregate evidence. Specifically, the likelihood of market participation increases by $37.7 \%, 10.7 \%, 23.1 \%, 28.0 \%$ and $8.8 \%$ for maize, groundnut, rice, beans and sorghum farmers, respectively, who engage in nonfarm work. The ATU estimates (from non-participants in nonfarm activities) confirm the ATT that nonfarm engagement increases the probability of selling crops. As Table 4 suggests, ATE estimates are consistently positive for aggregate crops and crop-specific market participation. Thus, nonfarm engagement increases the probability of market participation. Specifically, market participation increases by $30.7 \%, 33.0 \%, 22.9 \%, 46.0 \%, 46.5 \%$ and 9.9\% for maize, groundnuts, rice, beans, and sorghum, respectively. This contradicts Kan et al. (2006), who observed a negative effect of nonfarm engagement on market participation in Georgia. Therefore, we have evidence from these results that suggest that nonfarm participation does not only improve market participation of the sample of farmers but Ghanaian farmers in general.

Placing these findings in the context of the literature, they corroborate the existing evidence that report a positive effect of nonfarm activities or nonfarm income on market participation (e.g. Abdullah et al. 2019; Tudor and Balint 2006). However, they also contradict earlier findings (e.g. Canagarajah et al. 2001; Kan et al. 2006). While our evidence points to a complementary role of nonfarm engagement, earlier studies point to the opposite direction by indicating that participation in nonfarm activities and income resulting from them were competitive with agriculture. For example, Canagarajah et al. (2001) argued that nonfarm participation is viewed by farmers as an alternative livelihood diversification strategy away from agriculture, while Omiti et al. (2009), and Pfeiffer et al. (2009) were concerned that moving labour and land away from agriculture had negative consequences on farm productivity ultimately decreasing marketed surplus and dampening market participation. Further, our finding diverges from those of Woldehanna et al. (2016) who reported no statistical evidence of the effect of nonfarm income on output market participation decisions in Ethiopia.

To provide for further robustness check on the effect of nonfarm engagement on market participation, we used a control function approach suggested by Wooldridge (2014) to estimate two models that examine the effect of nonfarm engagement on crop sales value/income and crop sale quantity (in $\mathrm{kg}$ ). This approach is similar to the instrumental variable two-stage least squares model but different because the endogenous explanatory variable (nonfarm engagement) in this case is binary. The results are reported in Table 6 (in the Appendix). After controlling for all the relevant factors and instrumenting for nonfarm engagement using the exclusion restriction variables discussed earlier, the results show that nonfarm engagement is a positive correlate of both crop sale income and crop sale quantity. Specifically, farmers who engage in nonfarm activities earn GHS 1186.61 more in crop sales income and sell $879.96 \mathrm{~kg}$ more relative to farmers who do not participate in nonfarm activities. These estimates and findings corroborate 
the positive effect of nonfarm engagement on crop sale presented earlier and provide evidence that the positive effect of nonfarm engagement is generally robust to the measurement of market participation.

The last piece of the evidence tries to validate the liquidity-relaxing pathway through which nonfarm engagement positively affects market participation (as also shown in the conceptual model in Fig. 1). Being constrained in directly finding a variable for liquidity-relaxing, we rely on one of the main arguments for its role-ability to procure productivity-enhancing inputs, which boost productivity of farmers. We estimate models assessing the effect of nonfarm engagement on purchasing four inputs including inorganic fertiliser, improved seed, insecticide, and herbicide using the same control function approach mentioned earlier, with results displayed in Table 7 (in the Appendix). We find evidence that farmers who participate in nonfarm activities have higher likelihood of purchasing fertiliser, seed, insecticide, and herbicide relative to those not participating. Specifically, nonfarm participants are $60.3 \%, 44.6 \%, 72.2 \%$ and $87.1 \%$ more likely to purchase fertiliser, seed, insecticide, and herbicide, respectively. This evidence supports the liquidity-relaxing-effect hypothesis, which asserts that nonfarm work could provide additional liquidity for farm investment and increase output and marketable surplus (Woldehanna 2000). Indeed, for the specific case of Ghana, Okoh and Hilson (2011) observed that smallholder farmers who diversified into artisanal and small-scale mining invested portions of their incomes to boost their farm operations by procuring fertilisers. Further, this evidence is consistent with earlier findings on the positive effect of nonfarm participation on purchasing agricultural inputs and farm investments (Babatunde 2015; Maertens 2009; Dedehouanou et al. 2018; Anriquez and Daidone 2010).

We further explored the effect of nonfarm engagement on farm productivity as an indirect way of assessing the liquidity-relaxing hypothesis. The evidence (Table 7 in the Appendix) indicates that nonfarm participants achieve yields of $193 \mathrm{~kg} / \mathrm{ha}$ more relative to farmers who do not participate in nonfarm activities. This directly corroborates the findings of Anang (2017) which report that nonfarm participation positively affects farm productivity in Ghana, and indirectly the findings of Yang et al. (2014), and Anriquez and Daidone (2010) who observe improvement in technical efficiency due to participation in nonfarm activities in China and Ghana, respectively.

The validity of these results depends on the validity of the two instruments used - ease of finding jobs in community and people temporarily leaving community. We present validity tests of these instruments in Table 8 (in the Appendix). The Kleibergen-Paap LM statistic of under-identification is statistically significant providing the evidence that rejects the null hypothesis of under-identification of the instruments. In addition, the Hansen $J$ statistics for the various models are not significant and implies that we fail to reject the joint null hypothesis that the instruments are valid instruments (i.e. uncorrelated with the error term) and that the excluded instruments are correctly excluded from the estimated models. On the basis of all these results, the instruments are valid and relevant, and thus the estimated models are reliable. ${ }^{3}$

\footnotetext{
${ }^{3}$ The estimates from the ivreg2 also reports weak-identification test using the Cragg-Donald $F$ statistic with the StockYogo critical value providing the basis for its significance. However, due to the use of robust standard errors, the test becomes invalid and so not reported.
} 


\section{Conclusion and policy implications}

The study estimated the effect of nonfarm engagement of farmers on the sale of (i.e. smallholder market participation in) five crops-maize, beans, groundnut, rice, and sorghum. The endogenous switching probit was used to estimate the determinants of nonfarm engagement and market participation and based on the parameter estimates, the effects of nonfarm engagement on market participation were evaluated.

The main finding of this study is that nonfarm participation consistently increases the probability of selling crops as indicated by the ATE. Based on this finding, the study concludes that nonfarm engagement of farmers encourages market participation. The government of Ghana, like governments of other developing countries, acknowledges the importance of market engagements of farmers and their participation in nonfarm work. Indeed, there have been policy reforms across Africa to boost agriculture production and encourage subsistence farmers to sell their surplus on the one hand, and on the other hand, other reforms encourage diversification into nonfarm activities. However, a review of government policy documents in Ghana indicates there are no proposals for a simultaneous achievement of these two objectives. The conclusion of this study therefore points to a policy recommendation of revising policy documents and implementation processes to simultaneously tackle nonfarm engagement and market participation by farmers. A current candidate for review is the Planting for Food and Jobs (PFJ) initiative (2017-2022), which is a policy initiative launched in 2017 that aims to address Ghana's declining agricultural sector growth. It has five implementation modules including food crops, planting for export and rural development, greenhouse technology villages, rearing for food and jobs, and agricultural mechanisation services. In addition, potential policy initiatives should be conceived with strategies to achieve these two objectives. For example, the One District, One Factory (1D1F) initiative is a potential avenue to achieving these objectives. The 1D1F is a Government of Ghana special initiative which aims at fast-tracking industrialisation agenda in the country by promoting private sector-led industrialisation that empowers communities to use local resources to manufacture products in high demand both locally and internationally.

Further, we recommend that farm households can benefit more from market engagement by reallocating some time away from agricultural activities to participate in nonfarm activities and that income realised from these nonfarm activities should be channelled into reorienting farm production from subsistent driven to commercial one. Government policies to facilitate nonfarm activities and market participation can work better when farm households reorient themselves towards the path of these policies. Indeed, these findings apply to other developing countries.

We acknowledge this study has been unable to explore the effect of participating in multiple nonfarm activities or the effect of participating in nonfarm-specific activities on market participation. The focus has been on just participating in any nonfarm activity due to data limitations. Further, we have been unable to estimate the effect of nonfarm engagement on any direct liquidity-relaxing outcomes/variables, but rather used purchases of productivity-enhancing inputs, and crop productivity itself as indirect outcomes. These limitations of the current study provide pointers to the direction of future research in this area. 


\section{Appendix}

See Tables 5, 6, 7 and 8.

Table 5 Switch_probit estimates of determinants of nonfarm engagement and market participation for individual crops

\begin{tabular}{|c|c|c|c|c|c|c|c|c|c|}
\hline \multirow[t]{2}{*}{ Variable } & \multicolumn{3}{|c|}{ Sale of maize } & \multicolumn{3}{|c|}{ Sale of g'nut } & \multicolumn{3}{|c|}{ Sale of rice } \\
\hline & NFE & Part & Non-part & NFE & Part & Non-part & NFE & Part & Non-part \\
\hline $\begin{array}{l}\text { Age of } \\
\text { household } \\
\text { head }\end{array}$ & $-0.004^{* * *}$ & -0.003 & $-0.005^{* * *}$ & -0.003 & 0.000 & -0.002 & $-0.007^{* *}$ & 0.002 & $-0.007^{*}$ \\
\hline $\begin{array}{l}\text { Average } \\
\text { age of } \\
\text { household }\end{array}$ & $0.006^{* * *}$ & 0.007 & -0.001 & 0.005 & -0.003 & -0.003 & 0.006 & $-0.009^{*}$ & -0.009 \\
\hline $\begin{array}{l}\text { Sex of } \\
\text { household } \\
\text { head }\end{array}$ & -0.012 & -0.131 & $0.232^{* * *}$ & -0.111 & $0.283^{* *}$ & 0.214 & -0.158 & 0.114 & 0.117 \\
\hline $\begin{array}{l}\text { Years of } \\
\text { education } \\
\text { of head }\end{array}$ & $0.037^{* * *}$ & 0.013 & $-0.023^{* * *}$ & $0.018^{* *}$ & -0.011 & -0.022 & $0.018^{*}$ & -0.015 & 0.004 \\
\hline $\begin{array}{l}\text { Area of } \\
\text { residence }\end{array}$ & $-0.246^{*}$ & 0.044 & 0.205 & 0.026 & 0.403 & 0.204 & 0.005 & 0.447 & $0.677^{* *}$ \\
\hline $\begin{array}{l}\text { Farm size in } \\
\text { hectares }\end{array}$ & $n-0.010$ & 0.071 & $0.197^{* * *}$ & -0.002 & $0.251^{* * *}$ & 0.007 & $0.218^{* * *}$ & $0.212^{* * *}$ & 0.145 \\
\hline Price/kg & -0.009 & 0.004 & -0.028 & -0.013 & 0.029 & 0.036 & -0.003 & $-0.060^{* *}$ & $-0.146^{* * *}$ \\
\hline $\begin{array}{l}\text { Extension } \\
\text { office in } \\
\text { community }\end{array}$ & & $-0.706^{*}$ & -0.084 & & 0.003 & 0.179 & & $0.459^{* * *}$ & -0.101 \\
\hline $\begin{array}{l}\text { Agricultural } \\
\text { wage }\end{array}$ & -0.007 & -0.021 & $0.013^{* *}$ & $-0.022^{* *}$ & 0.002 & $0.035^{*}$ & -0.023 & $0.136^{* * *}$ & $0.118^{* * *}$ \\
\hline \multicolumn{10}{|l|}{$\begin{array}{l}\text { Ecological } \\
\text { zone (base: } \\
\text { Coastal): }\end{array}$} \\
\hline Forest & $-0.203^{*}$ & $5.868^{* * *}$ & 0.092 & $-0.752^{*}$ & $0.618^{*}$ & -0.092 & -0.777 & $-4.228^{* * *}$ & $5.962^{* * *}$ \\
\hline $\begin{array}{l}\text { Savan- } \\
\text { nah }\end{array}$ & $-0.546^{* * *}$ & $5.850^{* * *}$ & $0.290^{* *}$ & -0.275 & 0.249 & 0.006 & -0.985 & $-3.795^{* * *}$ & $6.213^{* * *}$ \\
\hline $\begin{array}{l}\text { Adult } \\
\text { equivalent } \\
\text { scale }\end{array}$ & $0.119 * * *$ & $0.052^{*}$ & $-0.061^{* * *}$ & $0.118^{* * *}$ & $-0.060^{* *}$ & -0.020 & $0.129 * * *$ & $-0.124^{* * *}$ & 0.032 \\
\hline $\begin{array}{l}\text { Market in } \\
\text { community }\end{array}$ & $y^{0.065}$ & $-0.576^{* * *}$ & -0.082 & 0.033 & $2.182^{* * *}$ & $-7.420^{* * *}$ & -0.055 & $-0.225^{* *}$ & $-0.256^{*}$ \\
\hline $\begin{array}{l}\text { Navigable } \\
\text { road to } \\
\text { community }\end{array}$ & $\begin{array}{l}-1.345^{* * *} \\
y\end{array}$ & $14.135^{* * *}$ & $0.764^{* * *}$ & & & & 0.096 & -0.120 & 0.181 \\
\hline $\begin{array}{l}\text { Public } \\
\text { transport } \\
\text { availability }\end{array}$ & $0.543^{* * *}$ & $-0.808^{* * *}$ & $-0.122^{* *}$ & $0.220^{* * *}$ & -0.139 & $-0.232^{* *}$ & $0.158^{*}$ & 0.021 & 0.053 \\
\hline $\begin{array}{l}\text { Ownership } \\
\text { of radio }\end{array}$ & 0.048 & 0.038 & $0.164^{* * *}$ & -0.058 & 0.140 & 0.177 & -0.109 & 0.010 & -0.001 \\
\hline $\begin{array}{l}\text { Bank in } \\
\text { community }\end{array}$ & $y^{0.388^{* * *}}$ & -0.091 & 0.107 & $0.347^{*}$ & $-0.368^{*}$ & 0.476 & 0.224 & -0.348 & 0.436 \\
\hline $\begin{array}{l}\text { Ease of jobs } \\
\text { in com- } \\
\text { munity }\end{array}$ & $0.115^{* *}$ & & & $0.142^{* *}$ & & & $0.267^{* * *}$ & & \\
\hline $\begin{array}{l}\text { Temporal } \\
\text { leaving of } \\
\text { community }\end{array}$ & $\begin{array}{l}0.158^{* * * *} \\
y\end{array}$ & & & $0.004^{* * *}$ & & & $0.075^{* *}$ & & \\
\hline Constant & -0.269 & $-7.536^{* * *}$ & $-1.298^{* * *}$ & -6.845 & -0.393 & 6.050 & 0.360 & $4.241^{* * *}$ & -7.556 \\
\hline $\begin{array}{l}\text { Control for } \\
\text { regional } \\
\text { dummies }\end{array}$ & Yes & Yes & Yes & Yes & No & No & Yes & Yes & Yes \\
\hline
\end{tabular}


Table 5 (continued)

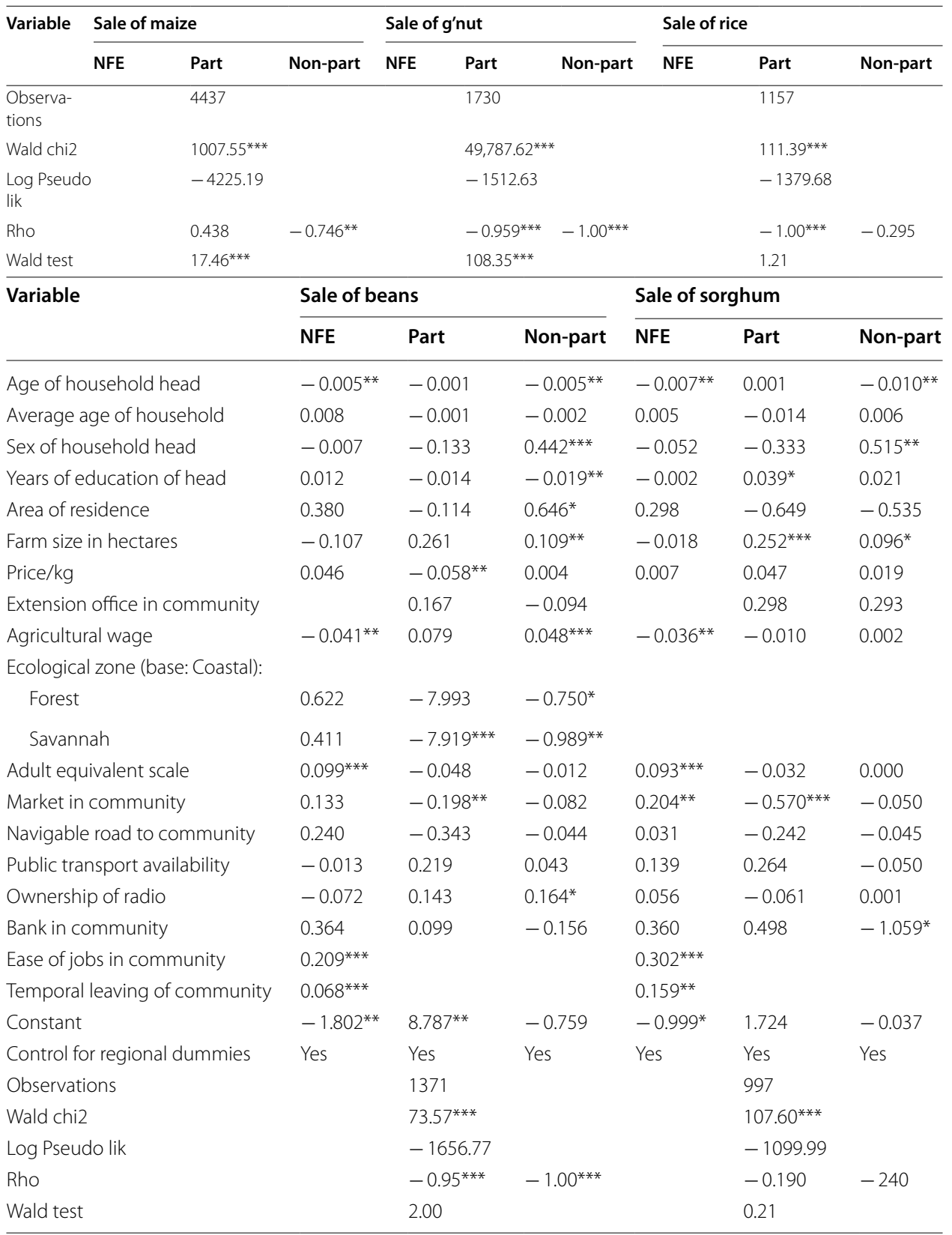

Source: Produced by the authors using the GLSS6 Data; ${ }^{*} p<0.1 ;{ }^{* *} p<0.05 ;{ }^{* *} p<0.01$ 
Table 6 Effect of NFE on sales value and sales quantity

\begin{tabular}{|c|c|c|c|}
\hline Variable & NFE & Sales (GHS) & Sales $(\mathbf{k g})$ \\
\hline Age of household head & $-0.003^{* *}$ & $-3.040^{* * *}$ & $-3.101^{* * *}$ \\
\hline Average age of household & $0.005^{* *}$ & 0.315 & 0.044 \\
\hline Sex of household head & -0.042 & $129.796^{* * *}$ & $188.025^{* * *}$ \\
\hline Years of education of head & $0.040^{* * *}$ & -2.269 & $-22.020^{* * *}$ \\
\hline Area of residence & $-0.243^{*}$ & 124.484 & 140.674 \\
\hline Farm size in hectares & -0.002 & $14.534^{* * *}$ & $25.660^{* * *}$ \\
\hline Price/kg & 0.006 & $30.109^{* * *}$ & $-7.574^{*}$ \\
\hline Extension office in community & & -69.227 & -66.553 \\
\hline Agricultural wage & -0.009 & $7.181^{*}$ & 1.542 \\
\hline \multicolumn{4}{|l|}{ Ecological zone (base: Coastal): } \\
\hline Forest & -0.175 & -38.124 & 13.278 \\
\hline Savannah & $-0.438^{* * *}$ & 62.959 & $334.239^{* * *}$ \\
\hline Adult equivalent scale & $0.112^{* * *}$ & $47.474^{* * *}$ & $45.709^{* * *}$ \\
\hline Market in community & -0.046 & 9.061 & $-143.448^{* * *}$ \\
\hline Navigable road to community & $-1.149^{* * *}$ & $690.072^{* * *}$ & $745.555^{* * *}$ \\
\hline Public transport availability & $0.460^{* * *}$ & -56.762 & -48.406 \\
\hline Ownership of radio & 0.034 & $128.845^{* * *}$ & $177.698^{* * *}$ \\
\hline Bank in community & $0.365^{* * *}$ & 21.340 & -66.112 \\
\hline Ease of jobs in community & $0.118^{* * *}$ & & \\
\hline Temporal leaving of community & $0.121^{* *}$ & & \\
\hline Nonfarm engagement & & $1186.606^{* * *}$ & $879.958^{* * *}$ \\
\hline Nonfarm engagement residual & & $215.244^{* *}$ & $-355.161^{* * *}$ \\
\hline Control for regional dummies & Yes & Yes & Yes \\
\hline Constant & -0.288 & $-772.096^{* * *}$ & $-794.972^{* * *}$ \\
\hline Observations & 4915 & 4915 & 4915 \\
\hline F-value & & $109.0^{* * *}$ & $36.07^{* * *}$ \\
\hline$R^{2}$ & 0.19 & 0.30 & 0.12 \\
\hline
\end{tabular}

Source: Produced by the authors using the GLSS6 Data; ${ }^{*} p<0.1 ;{ }^{* *} p<0.05 ;{ }^{* *} p<0.01$ 
Table 7 Effect of NFE on purchased inputs and productivity

\begin{tabular}{|c|c|c|c|c|c|}
\hline \multirow[t]{2}{*}{ Variable } & \multicolumn{4}{|l|}{ Purchased } & \multirow[t]{2}{*}{ Productivity } \\
\hline & Fertiliser & Seed & Insecticide & Herbicide & \\
\hline Age of household head & -0.002 & -0.001 & -0.002 & -0.002 & $-4.064^{* *}$ \\
\hline Average age of household & 0.000 & -0.002 & -0.000 & -0.001 & 2.968 \\
\hline Sex of household head & $0.185^{* * *}$ & 0.016 & $0.232^{* * *}$ & $0.281^{* * *}$ & 42.795 \\
\hline Years of education of head & 0.004 & $0.020^{* * *}$ & 0.010 & 0.008 & -1.135 \\
\hline Area of residence & $0.279^{* *}$ & 0.145 & 0.136 & 0.022 & 184.058 \\
\hline Farm size in hectares & 0.001 & -0.002 & 0.002 & 0.003 & $-7.056^{* *}$ \\
\hline Price/kg & $-0.012^{* *}$ & $0.044^{* * *}$ & -0.001 & -0.009 & $30.940^{* * *}$ \\
\hline Extension office in community & $0.134^{* *}$ & -0.049 & -0.055 & -0.045 & $-145.681^{*}$ \\
\hline Agricultural wage & -0.004 & $0.032^{* * *}$ & $-0.017^{* * *}$ & -0.005 & -7.557 \\
\hline \multicolumn{6}{|l|}{ Ecological zone (base: Coastal): } \\
\hline Forest & 0.041 & 0.038 & $0.437^{* * *}$ & $0.467^{* * *}$ & $-692.044^{* * *}$ \\
\hline Savannah & $0.907^{* * *}$ & -0.084 & $0.527^{* * *}$ & $0.405^{* * *}$ & $-1050.413^{* * *}$ \\
\hline Adult equivalent scale & 0.012 & $0.022^{*}$ & -0.004 & 0.007 & $52.189^{* * *}$ \\
\hline Market in community & $-0.169^{* * *}$ & 0.078 & -0.029 & -0.049 & 78.725 \\
\hline Navigable road to community & $0.336^{* * *}$ & -0.101 & $0.338^{* * *}$ & $0.453^{* * *}$ & -4.114 \\
\hline Public transport availability & $-0.137^{* * *}$ & -0.012 & -0.052 & -0.024 & $148.564^{* *}$ \\
\hline Ownership of radio & $0.135^{* * *}$ & 0.049 & $0.081^{*}$ & 0.062 & -68.140 \\
\hline Bank in this community & -0.148 & $0.209^{* *}$ & -0.100 & -0.051 & -90.835 \\
\hline Nonfarm engagement & $0.603^{* * *}$ & $0.446^{* *}$ & $0.722^{* * *}$ & $0.871^{* * *}$ & $193.277^{* * *}$ \\
\hline Nonfarm engagement residual & $-0.345^{* * *}$ & -0.037 & $-0.425^{* * *}$ & $-0.468^{* * *}$ & $431.117^{* * *}$ \\
\hline Control for regional dummies & Yes & Yes & Yes & Yes & Yes \\
\hline Constant & $-1.507^{* * *}$ & $-1.654^{* * *}$ & $-1.982^{* * *}$ & $-2.283^{* * *}$ & $1194.627^{* * *}$ \\
\hline Observations & 4915 & 4915 & 4915 & 4915 & 4915 \\
\hline LR Chi2 & $538.10^{* * *}$ & $314.22^{* * *}$ & $101.87^{* * *}$ & $105.44^{* * *}$ & \\
\hline F-value & & & & & $58.47^{* * *}$ \\
\hline Pseudo R2/R2 & 0.08 & 0.07 & 0.02 & 0.03 & 0.18 \\
\hline Log likelihood & -3090.44 & -2247.33 & -2220.31 & -1772.91 & \\
\hline
\end{tabular}

Source: Produced by the authors using the GLSS6 Data; ${ }^{*} p<0.1 ;{ }^{* *} p<0.05 ;{ }^{* * *} p<0.01$

Table 8 Validity tests of instruments

\begin{tabular}{lll}
\hline Outcome & $\begin{array}{l}\text { Test } \\
\text { Under-identification } \\
\text { Kleibergen-Paap LM statistic }\end{array}$ & $\begin{array}{l}\text { Over-identification } \\
\text { Hansen J statistic }\end{array}$ \\
\hline Sales quantity $(\mathrm{kg})$ & $11.946^{* * *}$ & $2.369(0.124)$ \\
Sales value $(\mathrm{GHS})$ & & $0.249(0.618)$ \\
Inorganic fertiliser & & $0.763(0.383)$ \\
Seed & & $0.724(0.127)$ \\
Insecticide & & $1.373(0.241)$ \\
Herbicide & $0.073(0.787)$ \\
Productivity & & $0.059(0.808)$ \\
\hline
\end{tabular}

$p$ values in parenthesis; ${ }^{* * *} p<0.01$ 


\section{Acknowledgements}

The authors acknowledge the valuable contributions of participants of the Partnership for Economic Policy (PEP) Annual Conferences at which the study was presented. We also gratefully acknowledge the helpful comments of two anonymous referees and the editor in improving the paper. However, the usual disclaimer applies.

\section{Authors' contributions}

All authors conceived of and planned the study. PKN, BMA, YU and HA acquired the data and performed statistical analysis with guidance from AA. PKN, BMA, YU and HA drafted the manuscript, and AA, EDS and SAW critically reviewed it for important intellectual content. All authors read and approved the final manuscript.

\section{Funding}

This study was completed with financial and scientific support from the Partnership for Economic Policy (PEP) and with funding from the Department for International Development (DFID) of the United Kingdom (UK Aid) and from the Government of Canada through the International Development Research Centre (IDRC). The views and opinions expressed in this paper are those of the authors and do not necessarily reflect those of PEP.

\section{Availability of data and materials}

The datasets used and/or analysed during the current study are available from the corresponding author on request.

\section{Declarations}

\section{Competing interests}

The authors declare that they have no competing interests.

\section{Author details}

'Department of Economics and Entrepreneurship Development, University for Development Studies, P. O. Box 520, Wa, Upper West Region, Ghana. ${ }^{2}$ Department of Economics, University of Laval, Quebec, Canada. ${ }^{3}$ Department of Agricultural and Resource Economics, University for Development Studies, Tamale, Ghana.

Received: 2 May 2021 Revised: 7 January 2022 Accepted: 11 January 2022

Published online: 09 February 2022

\section{References}

Abdullah, Rabbi F, Ahamad R, Ali S, Chandio AA, Ahmad W, Llyas A, Din IU (2019) Determinants of commercialization and its impact on the welfare of smallholder rice farmers by using Heckman two-stage approach. J Saudi Soc Agric Sci 18(2):224-233

Abu BM, Issahaku H, Nkegbe PK (2016) Farmgate versus market centre sales: a multi-crop approach. Agric Food Econ $4(1): 1-16$

Ackah C (2013) Nonfarm employment and incomes in rural Ghana. J Int Dev 25(3):325-339

Akudugu MA, Guo E, Dadzie SK (2012) Adoption of modern agricultural production technologies by farm households in Ghana: What factors influence their decisions? J Biol Agric Healthc 2(3):1-13

Alasia A, Weersink A, Bollman RD, Cranfield J (2009) Off-farm labour decision of Canadian farm operators: urbanization effects and rural labour market linkages. J Rural Stud 25(1):12-24

Alemu AE, Adesina JO (2017) In search of rural entrepreneurship: nonfarm household enterprises (NFEs) as instruments of rural transformation in Ethiopia. Afr Dev Rev 29(2):259-271

Alhassan H, Abu BM, Nkegbe PK (2020) Access to credit, farm productivity and market participation in Ghana: a conditional mixed process approach. Margin J Appl Econ Res 14(2):226-246

Anang BT (2017) Effect of nonfarm work on agricultural productivity: empirical evidence from northern Ghana. WIDER working paper No. 2017/38

Anríquez G, Daidone S (2010) Linkages between the farm and nonfarm sectors at the household level in rural Ghana: a consistent stochastic distance function approach. Agric Econ 41(1):51-66

Babatunde RO (2015) On-farm and off-farm works: Complement or substitute? Evidence from Nigeria. Maastricht School of Management Working Paper 2015/02. University of Ilorin, Department of Agricultural Economics and Farm Management, llorin

Barrett CB (2008) Smallholder market participation: concepts and evidence from Eastern and Southern Africa. Food Policy 33(4):299-317

Barrett CB, Reardon T, Webb P (2001) Nonfarm income diversification and household livelihood strategies in rural Africa: concepts, dynamics and policy implications. Food Policy 26(4):315-331

Benedikter S, Waibel G, Birtel S, Bui CT, Tran BT (2013) Local entrepreneurship in Viet Nam's rural transformation: a case study from the Mekong Delta. Centre for Development Research (ZEF), Can Tho City Institute for Socio-Economic Development Studies (CIDS), Southern Institute of Social Sciences (SISS), Bonn

Canagarajah S, Newman C, Bhattamishra R (2001) Non-farm income, gender, and inequality: evidence from rural Ghana and Uganda. Food Policy 26(4):405-420

Chang H, He J, Saeliw K (2017) The role of off-farm labor participation decisions of married farm couples on farm direct marketing in Taiwan. Dev Econ 55(1):3-22

Dedehouanou SFA, Araar A, Ousseini A, Harouna AL, Jabir M (2018) Spillovers from off-farm self-employment opportunities in rural Niger. World Dev 105:428-442

Ellis F (2000) The determinants of rural livelihood diversification in developing countries. J Agric Econ 51 (2):289-302 
Hilson G (2010) 'Once a miner, always a miner': poverty and livelihood diversification in Akwatia, Ghana. J Rural Stud 26(3):296-307

Hilson G, Garforth CJ (2013) Everyone now is concentrating on the mining': drivers and implications of rural economic transition in the Eastern Region of Ghana. J Dev Stud 49(3):348-364. https://doi.org/10.1080/00220388. 2012.713469

Hoang TX, Pham CS, Ulubasoglu MA (2014) Nonfarm activity, household expenditure, and poverty reduction in rural Vietnam: 2002-2008. World Dev 64:554-568

Holden S, Shiferraw B, Pender J (2004) Nonfarm income, household welfare, and sustainable land management in a less favoured area in Ethiopian Highlands. Food Policy 29:369-392

Hussain A, Thapa GB (2016) Fungibility of smallholder agricultural credit: empirical evidence from Pakistan. Eur J Dev Res 28(5):826-846

Kan I, Kimhi A, Lerman Z (2006) Farm output, nonfarm income, and commercialization in rural Georgia. eJADE Electron J Agric Dev Econ 3(2):276-286

Kilic T, Carletto C, Miluka J, Savastano S (2009) Rural nonfarm income and its impact on agriculture: evidence from Albania. Agric Econ 40:139-160

Lokshin M, Sajaia Z (2011) Impact of interventions on discrete outcomes: maximum likelihood estimation of the binary choice models with binary endogenous regressors. Stata J 11(3):368-385

Maertens M (2009) Horticulture exports, agro-industrialization and farm-nonfarm linkages with the small farm sector: evidence from Senegal. Agric Econ 40:219-229

Muamba FM (2011) Selling at the farmgate or traveling to the market: a conditional farm-level model. J Dev Areas 44(2):95-107

Okoh G, Hilson G (2011) Poverty and livelihood diversification: exploring the linkages between smallholder farming and artisanal mining in rural Ghana. J Int Dev 23(8):1100-1114

Olugbire OO, Falusi AO, Adeoti Al, Oyekale AS (2012) Determinants of nonfarm income diversification among rural households in Nigeria. J Am Sci 8(1):77-82

Omiti JM, Otieno DJ, Nyanamba TO, McCullough E (2009) Factors influencing the intensity of market participation by smallholder farmers: a case study of rural and peri-urban areas of Kenya. Afr J Agric Resour Econ 3(1):57-82

Osarfo D, Senadza B, Nketiah-Amponsah E (2016) The impact of nonfarm activities on rural farm household income and food security in the upper east and upper west regions of Ghana. Theor Econ Lett 6(3):388-400

Otekunrin OA, Momoh S, Ayinde IA (2019) Smallholder farmers' market participation: concepts and methodological approaches from Sub-Saharan Africa. Curr Agric Res J 7(2):139-157. https://doi.org/10.12944/CARJ.7.2.02

Owusu V, Abdulai A, Abdul-Rahaman S (2011) Nonfarm work and food security among farm households in northern Ghana. Food Policy 36:108-118

Pfeiffer L, López-Feldman A, Taylor JE (2009) Is off-farm income reforming the farm? Evidence from Mexico. Agric Econ 40(2):125-138

Reardon T (1997) Using evidence of household income diversification to inform study of the rural nonfarm labor market in Africa. World Dev 25(5):735-747

Reardon T, Crawford E, Kelly V (1994) Link between nonfarm income and farm investment in African households: adding the capital market perspective. Am J Agric Econ 76:1172-1176

Reardon T, Berdegué J, Barrett CB, Stamoulis K (2007) Household income diversification into rural nonfarm activities. In: Haggblade S, Hazell PBR, Reardon T (eds) Transforming the rural nonfarm economy. Opportunities and threats in the developing world. Johns Hopkins University Press, Baltimore, pp 55-79

Sekyi S, Abu BM, Nkegbe PK (2017) Farm credit access, credit constraint and productivity in Ghana: empirical evidence from northern savannah ecological zone. Agric Finance Rev 77(4):446-462

Seng K (2016) The effects of market participation on farm households'food security in Cambodia: an endogenous switching approach. MPRA paper no. 69669.

Singh I, Squire L, Strauss J (1986) Agricultural Household models. Johns Hopkins University Press, Baltimore

Smale M, Kusunose Y, Mathenge MK, Alia D (2016) Destination or distraction? Querying the linkage between off-farm work and food crop investments in Kenya. J Afr Econ 25(3):388-417

Tudor M, Balint B (2006) Off-farm employment and agricultural sales: evidence from Romania. Post-Commun Econ 18(2):243-260

Woldehanna T (2000) Economic analysis and policy implication of farm and off-farm employment: a case study in the Tigray region of northern Ethiopia. Mansholt Studies 18 and PhD Thesis, Agricultural Economics and Rural Policy Group, Wageningen University

Woldehanna T, Oskam A (2001) Off-farm employment and income inequality: the implication for poverty reduction strategy. Ethiop J Econ 4:41-57

Woldehanna T, Heckelei T, Surry Y (2016) Effect of off-farm income on smallholder commercialization: panel evidence from rural households in Ethiopia. Agric Econ 48(2):207-218

Wooldridge JM (2014) Control function methods in applied econometrics. J Hum Resour 50(2):420-445

Yang J, Wang H, Jin S, Chen K, Riedinger J, Peng C (2014) Migration, local off-farm employment and agricultural production efficiency: Evidence from China. Selected paper prepared for presentation at the agricultural and applied economics association's 2014 AAEA annual meeting, Minneapolis, MN, July 27-29, 2014

\section{Publisher's Note}

Springer Nature remains neutral with regard to jurisdictional claims in published maps and institutional affiliations. 